\title{
Adequacy of energy and macronutrient intake of food supplements for athletes
}

\section{Suplementos alimentares na adequação do consumo energético e de macronutrientes em atletas}

\author{
Vanessa Behrends RODRIGUES 1 \\ Christianne de Faria Coelho RAVAGNANI ${ }^{2}$ \\ Hellen Clair Garcêz NABUCO ${ }^{3}$ \\ Fabrício César de Paula RAVAGNANI ${ }^{4}$ \\ Vânia Letícia Souza FERNANDES ${ }^{1}$ \\ Mariano Martínez ESPINOSA 5
}

A B S T R A C T

\section{Objective}

To assess how much food supplements contribute to the nutritional adequacy of energy and macronutrients in relation those recommended for athletes.

\section{Methods}

This was a cross sectional study was composed of 182 athletes from 19 sports (150 men and 32 women) with a mean age, weight, height and body mass index of $23.8 \pm 7.5$ years, $73.7 \pm 15.6 \mathrm{~kg}, 1.7 \pm 0.1 \mathrm{~m}, 24.2 \pm 4.0 \mathrm{~kg} / \mathrm{m}^{2}$, respectively. The 24 hours dietary recall was applied to assess intake and the Multiple Source Method to evaluate usual intake. We used the $t$-test, Mann-Whitney test, Analysis of Variance and Kruskal-Wallis for comparative

1 Universidade Federal de Mato Grosso, Faculdade de Nutrição, Programa de Pós-Graduação em Biociências. Av. Fernando Corrêa da Costa, 2367, Boa Esperança, 78060-900, Cuiabá, MT, Brasil. Correspondência para/Correspondence to: VB RODRIGUES. E-mail: <vanessabehrends@gmail.com>.

${ }^{2}$ Universidade Federal de Mato Grosso, Departamento de Educação Física, Programa de Pós-Graduação em Educação Física. Cuiabá, MT, Brasil.

3 Instituto Federal de Educação, Ciência e Tecnologia de Mato Grosso, Departamento de Administração e Planejamento. Cuiabá, MT, Brasil.

${ }^{4}$ Instituto Federal de Educação, Ciência e Tecnologia de Mato Grosso, Departamento de Ensino, Pesquisa e Extensão. Cuiabá, MT, Brasil.

${ }^{5}$ Universidade Federal de Mato Grosso, Instituto de Ciências Exatas e da Terra, Departamento de Estatística. Cuiabá, MT, Brasil.

Article based on the master's thesis of VB RODRIGUES, entitled "Avaliação da adequação energética e de macronutrientes em atletas". Universidade Federal de Mato Grosso; 2015.

Support: Coordenação de Aperfeiçoamento de Pessoal Nivel Superior and Conselho Nacional de Desenvolvimento Científico e Tecnológico (Process no 446323/2014-4). 
analysis among the diets, gender and types of groups, and the comparison of two-proportion test to assess the diets Food and Food and Supplementation.

\section{Results}

Of the athletes studied, less than half used dietary supplements (39.0\%). Energy intake was below the recommended $(52.7 \%)$ in Food diet, and $45.6 \%$ in Food and Supplementation diet. The mean total of carbohydrate inadequacy $\left(\mathrm{g} \cdot \mathrm{kg}^{-1}\right.$. day $\left.{ }^{-1}\right)$ was high for athletes of both genders and between Food and Food and Supplementation diets. The protein intake was above the recommended levels in Food diet (23.1\%) and in Food and Supplementation diet (33.5\%). The lipid intake was also above the recommended dietary levels in Food $(47.3 \%)$ and in Food and Supplementation diets (50.0\%).

\section{Conclusion}

The use of supplements did not significantly reduce inadequacies of diet and the athletes' intake of calories and carbohydrates was below the recommended for these groups. However, the protein intake was above the recommended levels for athletes.

Keywords: Diet. Food consumption. Nutritional assessment.

\section{RE S U M O}

\section{Objetivo}

Avaliar a contribuição dos suplementos alimentares para a adequação nutricional de energia e macronutrientes em relação às recomendações propostas para atletas.

\section{Métodos}

Estudo transversal, composto por 182 atletas de 19 modalidades esportivas (150 homens e 32 mulheres),

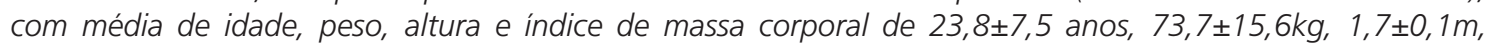
$24,2 \pm 4,0 \mathrm{~kg} / \mathrm{m}^{2}$, respectivamente. Foi aplicado recordatório de 24 horas para avaliação do consumo e o Multiple Source Method para avaliação do consumo usual. Foram usados: teste-t, Mann-Whitney, Analises de Variância e Kruskal-Wallis para análise de comparação entre as dietas, por gênero e grupos de modalidades, e teste de comparação entre duas proporções para avaliar as dietas Alimentos e Alimentos e Suplementos.

\section{Resultados}

Menos da metade fazia uso de suplementos alimentares (39,0\%). O consumo energético esteve abaixo do recomendado em 52,7\% na dieta Alimentos, e 45,6\% na dieta Alimentos e Suplementos. A inadequação de carboidrato $\left(\mathrm{g} \cdot \mathrm{kg}^{-1} \cdot \mathrm{dia}^{-1}\right)$ foi alta na média total de atletas, para gêneros e entre modalidades nas dietas Alimentos e Alimentos e Suplementos. O consumo proteico esteve acima do recomendado em $23,1 \%$ na dieta Alimentos e 33,5\% na dieta Alimentos e Suplementos. Já para lipídeos a ingestão esteve acima do recomendado 47,3\% na dieta Alimentos e 50,0\% na dieta Alimentos e Suplementos.

\section{Conclusão}

O uso de suplementos não auxiliou na diminuição das inadequações de forma expressiva, permanecendo os atletas abaixo das recomendações preconizadas para calorias e glicídios, porém aumentou a quantidade de atletas acima da recomendação de proteína.

Palavras-chave: Dieta. Consumo de alimentos. Avaliação nutricional.

\section{NTRODUCTION}

The importance of nutrition for athletic performance and health maintenance of athletes is well documented in the literature [1]. Based on this, a number of sports associations and societies have issued specific recommendations regarding the daily intake of energy, macronutrients and use of dietary supplements among sportsmen and sportswomen [1,2]. However, previous studies have shown that intake of athletes from different sports and continents does not reach the recommended values according to these documents $[3,4]$, confirming the need for nutritional interventions by experts $[5,6]$. 
The intake of dietary supplements has increasingly become more widespread among athletes [7], generating billions of dollars annually [8]. However, the use of supplements is not always based on nutritional deficiencies, efficacy, safety or legality, leading to unnecessary costs for athletes, clubs and/or sponsors, in addition to the risk of positive doping [9]. Although they are used for a wide range of purposes in sports (as stimulants, sleep enhancement, water replenishment, fatigue reduction and stored body fat), one of the primary functions of nutritional supplements is to help athletes achieve their higher daily needs of energy and nutrients due to training [9].

Although there is relative consensus regarding the important role of these products in preventing negative energy balance and its consequent damages (i.e., loss of muscle mass, menstrual dysfunction, bone density reduction, increased risk of fatigue and injuries) [1], few studies have analyzed the contribution of adequate supplementation of energy intake and macronutrients for athletes. Most studies on sports supplementation focus on the ergogenic effects and/or substance use profiles.

In this respect, in one of the few studies involving athletes of different sports modalities, Lun et al. [4] showed that the use of supplements by Canadian sportsmen and sportswomen significantly increased the average macronutrient and micronutrient values of the diet, although calories and carbohydrates were below the recommended level. Taking into account that food consumption may be influenced by demographic, cultural, environmental, and physical training factors, the aforementioned results may not reflect the reality of Brazilian athletes, thus the need for further studies on this subject. In addition, in the same article, no data were reported on whether or not there was a decrease in insufficient intake and/ or excessive intake of macronutrients due to the use of supplements.

Considering the importance of these indicators for the health and physical performance of these individuals, knowledge of the athletes' nutritional profile is fundamental for proposing and implementing culturally appropriate education and intervention programs. In addition, this study aims to provide a current view of the dietary intake of these athletes including the use of dietary supplements covering various distinctive sports modalities and thus serving as reference for nutritionists in their clinical settings where they generally attend heterogeneous athletic audiences.

Therefore, the aim of the present study was to describe the energy and macronutrient intake of athletes and assess the extent to which dietary supplements contribute to nutritional adequacy in relation to the recommendations for this public.

\section{METHODS}

This study is part of the research 'Validation of Food Frequency Questionnaire for Athletes' (Protocol CNPq 2773018526090972). It is a cross-sectional study, carried out from December 2013 to October 2014. Athletes were individuals associated with sports federations of different sports modalities in the state of Mato Grosso who participated in regional and international competitions.

The recruitment of the athletes was carried out through the federations, by e-mail, telephone, in person or directly with the coaches. Athletes between 14 and 49 years old, of both sexes, from all sports modalities, were selected for the study, totaling a sample of 182 athletes, of which 150 were men and 32 women, from 19 different sports modalities.

Demographic and training information were obtained through a questionnaire. Food consumption and dietary supplements were assessed by the 24-Hour Dietary Recall (24-HDR) method applied on two non-consecutive days of the week, with the aid of a photographic record taken during an interview [10]. All 
athletes were instructed to report the types of food preparation (fried, roasted, grilled, etc) as well as the addition of oil, salt, sugar and other seasonings in the preparations. Participants who were on food and supplementation were instructed to report the brand and quantity consumed due to the variation of macronutrient values present in each supplement.

Any product ingested orally was considered a food supplement for diet complementation, which may be composed of: vitamins, minerals, herbs or plant products, amino acids, among others [11].

The home measurements of the nutritional values of food and supplementation were converted into grams and milliliters by the online software Virtual Nutri Plus (Keeple ${ }^{\circledR}$, Rio de Janeiro, RJ, Brazil) for diet analysis. Some foods were not found in the program database and therefore items were added from food tables [12-14]. As for the supplements, the nutritional labels on the products were used. Additional information regarding the prevalence of intake and the types of dietary supplements used by the study population can be found in a previously published article [15].

To reduce errors in the estimation of normal intake, the Multiple Source Method program (Department of Epidemiology of the German Institute of Human Nutrition PotsdamRehbrücke) was used. This program generates information regarding the estimated habitual intake of an individual, combining probability using repetitions of 24-hour recall or food record, added or not to the application of a food frequency questionnaire [16]. Details of the method can be found at <https://msm. dife.de>. For the supplement intake, the mean consumption of two days was used. The assessments were carried out by a previously trained multidisciplinary team. A pilot was conducted with athletes who were not included in the present sample to correct possible errors present in the questionnaires and to standardize their application.
The nutritional adequacy of energy and macronutrients were comparatively assessed with the Brazilian nutritional guide for athletes recommended by the Brazilian Society of Sports Medicine [2], as shown in Table 1.

For the purpose of categorizing the types of modalities, sports modalities with duration of less than 3 minutes with a considerable rest interval, such as bodybuilding and swimming, were considered as power/speed sports [4]. Intermittent sports were those with short intervals during the game, such as volleyball and soccer [17]. In the category fighting/shooting sports the following were considered: Karate, Judo, shooting, among others. Endurance sports were those modalities with duration greater than 3 minutes and without intervals during the event, such as triathlon and cycling [4]. The groups were classified by modalities in: power/ speed ( $n=35)$; intermittent $(n=77)$; fighting/ shooting ( $n=56)$; and endurance $(n=14)$.

The present study was approved by the Research Ethics Committee of the Hospital Universitário Júlio Müller under $\mathrm{n}^{\circ}$ 25620713.3.0000.5541. The research objectives were explained to all participants or their parents or guardians if minors and they signed a Free and Informed Consent.

Body weight and height were measured using a mechanical scale with $100 \mathrm{~g}$ gradation (Welmy ${ }^{\circledR}$, Santa Barbara d'Oeste, São Paulo, Brazil) and a $0.1 \mathrm{~cm}$ (Sanny ${ }^{\circledR}$, American Medical

Table 1. Daily reference values for energy and macronutrient intake among athletes.

\begin{tabular}{|c|c|}
\hline Macronutrients/energy & SBME (2009) \\
\hline Energy (kcal.day ${ }^{-1}$ ) & $3000.0-5000.0$ \\
\hline Energy (kcal.Kg.day ${ }^{-1}$ ) & $30.0-50.0$ \\
\hline Protein (g.kg. ${ }^{-1}$ day $^{-1}$ ) & $1.2-1.7$ \\
\hline Carbohydrate $\left(\mathrm{g} \cdot \mathrm{kg}^{-1} \cdot\right.$ day $\left.^{-1}\right)$ & $5.0-10.0$ \\
\hline Lipids (g.kg-1 .day $\left.^{-1}\right)$ & 1.0 \\
\hline Carbohydrate (\%) & $60.0-70.0$ \\
\hline Lipids (\%) & 30.0 \\
\hline
\end{tabular}

Note: Brazilian Society of Sports Medicine (SBME). 
do Brasil Ltda, São Bernardo do Campo, São Paulo, Brazil) portable stadiometer. The Body Mass Index $\left(\mathrm{BMI}=\mathrm{kg} / \mathrm{m}^{2}\right)$ was calculated and used as an indicator for the nutritional status of the athletes, considering gender and age $[18,19]$.

The energy expenditure at rest was estimated using the formula proposed by World Health Organization [20]. The energy expenditure of physical activities was then estimated using the Compendium of Physical Activity, proposed by Ainsworth et al. [21]. The values of the basal energy expenditure and the energy expenditure of activities were added, thus estimating the daily energy expenditure for each athlete [22].

Statistical analyses were performed using the Statistical Package for Social Sciences (SPSS Inc., Chicago, Illinois, United States) version 17.0. The variables were compared by gender and intake Food (F) and Food and Supplementation $(F+S)$ using the Student's $t$-test for independent samples, for variables with normal distribution, and the Mann-Whitney test for variables with non-normal distribution. To compare the sports modalities, these were divided into 4 groups (power/speed, intermittent, fighting/shooting and endurance). The One Way Analysis Variance tests were applied for the parametric data and the Kruskal-Wallis for non-parametric data. The Shapiro-Wilk test was used to verify distribution which was considered normal if $p$ was greater than 0.05 .

For the evaluation of inadequate percentages, the test was used for two proportions, performed by the Minitab statistical package (State College, Pennsylvania, United States), version 15 . In all analyses, $p$ was considered statistically significant if lower than 0.05 $(p<0.05)$.

\section{RE S U L T S}

Of the 182 athletes evaluated, 39.0\% supplemented their diet. More than half of the individuals did not have a health insurance plan $(51.7 \%)$ and their family income was up to 4 minimum wages (50.6\%). Most athletes were in the pre-competitive period (68.7\%). Other information such as: anthropometric characteristics, training of individuals, gender and groups of sports modalities, as well as the appropriate statistical comparisons, are shown in Table 2.

The mean and standard deviation for all participants with respect to their weight and height were $23.8 \pm 7.5$ and $1.7 \pm 0.1$, respectively. The BMI revealed that most athletes were well-

Table 2. Anthropometric and training characteristics of participants according to gender and groups of sports modalities. Cuiabá (MT), Brazil (2014)

\begin{tabular}{|c|c|c|c|c|c|c|c|}
\hline \multirow{2}{*}{ Athletes } & \multirow{2}{*}{$n$} & \multicolumn{2}{|c|}{ Age-years } & \multicolumn{2}{|c|}{ BMI $\left(\mathrm{kg} / \mathrm{m}^{2}\right)$} & \multicolumn{2}{|c|}{ Hours of daily training ${ }^{* *}$} \\
\hline & & M & SD & M & SD & M & SD \\
\hline All participants & 182 & 23.8 & 7.5 & 24.2 & 4.0 & 3.0 & 2.1 \\
\hline Women & 32 & 20.6 & 7.7 & 21.1 & 2.1 & 2.8 & 1.3 \\
\hline Men & 150 & 24.5 & $7.3^{*}$ & 24.9 & $4.0^{*}$ & 3.1 & 2.2 \\
\hline Power/speed & 35 & 21.6 & 4.9 & 24.2 & 4.4 & 2.3 & 1.2 \\
\hline Intermittent & 77 & 24.2 & 6.6 & 24.6 & 3.8 & 3.5 & 1.4 \\
\hline Fighting/shooting & 56 & 23.4 & 8.9 & 24.1 & 4.8 & 2.5 & $1.1^{\mathrm{ab}}$ \\
\hline Endurance & 14 & 28.6 & 12.5 & 22.4 & 1.7 & 3.1 & 1.1 \\
\hline
\end{tabular}

Note: "Significant difference between genders, $p<0.05 ;{ }^{* *}$ The total sample for this variable was: men=148 and women=32

Different letters indicate statistical difference between groups, where apower/speed, bintermittent.

BMI: Body Mass Index; M: Mean; SD: Standard Deviation. 
Table 3. Mean and standard deviation of energy and macronutrient intake for Food (F) and Food and Supplementation $(F+S)$ for all individuals and genders. Cuiabá (MT), Brazil (2014).

\begin{tabular}{|c|c|c|c|c|c|c|c|}
\hline \multirow{2}{*}{ Macronutrients } & \multirow{2}{*}{$\mathrm{F}$ and $\mathrm{F}+\mathrm{S}$} & \multicolumn{2}{|c|}{ Total $(\mathrm{N}=182)$} & \multicolumn{2}{|c|}{ Women $(n=32)$} & \multicolumn{2}{|c|}{ Men $(n=150)$} \\
\hline & & M & SD & M & SD & M & SD \\
\hline \multirow[t]{2}{*}{ kcal.day ${ }^{-1}$} & $\mathrm{~F}$ & 2188.0 & 591.0 & 1954.0 & 436.0 & 2238.0 & $609.0^{*}$ \\
\hline & $\mathrm{F}+\mathrm{S}$ & 2300.0 & 661.0 & 2049.0 & 420.0 & 2354.0 & $691.0^{*}$ \\
\hline \multirow[t]{2}{*}{ kcal.kg ${ }^{-1} \cdot$ day $^{-1}$} & $\mathrm{~F}$ & 31.0 & 9.0 & 37.0 & $10.0^{*}$ & 29.0 & 9.0 \\
\hline & $\mathrm{F}+\mathrm{S}$ & 32.0 & 10.0 & 39.0 & $9.0^{*}$ & 31.0 & 9.0 \\
\hline \multirow[t]{2}{*}{$\mathrm{CHO}\left(\mathrm{g} \cdot \mathrm{kg}^{-1} \cdot \mathrm{day}^{-1}\right)$} & $\mathrm{F}$ & 3.9 & 1.4 & 4.6 & $1.6^{*}$ & 3.6 & 1.3 \\
\hline & $\mathrm{F}+\mathrm{S}$ & 3.9 & 1.4 & 4.7 & $1.5^{*}$ & 3.7 & 1.3 \\
\hline \multirow[t]{2}{*}{$\mathrm{CHO}\left(\right.$ g.day $\left.^{-1}\right)$} & $\mathrm{F}$ & 270.0 & 87.0 & 243.9 & 81.1 & 275.1 & 87.2 \\
\hline & $\mathrm{F}+\mathrm{S}$ & 276.0 & 86.9 & 249.3 & 78.1 & 281.7 & $87.8^{*}$ \\
\hline \multirow[t]{2}{*}{$\mathrm{CHO}(\%)$} & $\mathrm{F}$ & 49.3 & 8.3 & 49.4 & 9.1 & 49.3 & 8.1 \\
\hline & $\mathrm{F}+\mathrm{S}$ & 48.3 & 8.3 & 48.3 & 9.7 & 48.3 & 8.0 \\
\hline \multirow[t]{2}{*}{ Protein $\left(\mathrm{g} \cdot \mathrm{kg}^{-1} \cdot \mathrm{day}^{-1}\right)$} & $\mathrm{F}$ & 1.5 & $0.6^{+}$ & 1.8 & $0.8^{*}$ & 1.4 & 0.6 \\
\hline & $\mathrm{F}+\mathrm{S}$ & 1.7 & $0.8^{+}$ & 2.1 & $0.9^{*}$ & 1.6 & 0.8 \\
\hline \multirow[t]{2}{*}{ Protein (g.day ${ }^{-1}$ ) } & $\mathrm{F}$ & 104.6 & $45.2^{+}$ & 95.3 & 35.0 & 106.6 & 46.9 \\
\hline & $\mathrm{F}+\mathrm{S}$ & 120.0 & $62.1^{+}$ & 110.3 & 46.8 & 122.1 & 64.8 \\
\hline \multirow[t]{2}{*}{ Protein (\%) } & $\mathrm{F}$ & 19.0 & $5.7^{+}$ & 20.1 & 7.2 & 18.8 & 5.3 \\
\hline & $\mathrm{F}+\mathrm{S}$ & 20.4 & $6.6^{t}$ & 21.8 & 8.8 & 20.1 & 6.1 \\
\hline \multirow[t]{2}{*}{ Lipids (g.kg ${ }^{-1} \cdot$ day $\left.^{-1}\right)$} & $\mathrm{F}$ & 1.1 & 0.4 & 1.3 & $0.4^{*}$ & 1.0 & 0.4 \\
\hline & $\mathrm{F}+\mathrm{S}$ & 1.1 & 0.4 & 1.3 & $0.4^{*}$ & 1.0 & 0.4 \\
\hline \multirow[t]{2}{*}{ Lipids (g.day ${ }^{-1}$ ) } & $\mathrm{F}$ & 74.7 & 24.2 & 66.7 & 17.9 & 76.4 & 25.1 \\
\hline & $\mathrm{F}+\mathrm{S}$ & 75.8 & 24.2 & 67.4 & 17.6 & 77.6 & 25.0 \\
\hline \multirow[t]{2}{*}{ Lipids (\%) } & $\mathrm{F}$ & 30.8 & 5.6 & 30.6 & 4.4 & 30.8 & 5.8 \\
\hline & $\mathrm{F}+\mathrm{S}$ & 30.0 & 6.0 & 29.6 & 5.2 & 30.1 & 6.1 \\
\hline Energy expenditure & $\mathrm{kcal}^{-1} \cdot$ day $^{-1}$ & 3277.0 & 1230.0 & 2221.4 & 606.0 & 3516.9 & $1210.0^{* d}$ \\
\hline
\end{tabular}

Note: Values reported as mean (standard deviation). 'Significant difference between intake of Food (F) and Food and Supplementation ( $F+S$ ) diets for Protein (PTN) g.day-1, PTN g.kg-1.day-1, and PTN percentage; "Significant difference between genders for energy expenditure ( $n=173)$, Carbohydrates (CHO) g.day-1 F+S and kcal.day-1, kcal.kg-1.day-1 CHO, PTN and lipids g.kg-1.day-1 in F and F+S diets, where $p<0.05$; \#Student's $t$-test for fat percentage and Mann Whitney test for the other variables were used to compare genders.

M: Mean; SD: Standard Deviation.

nourished (63.7\%), but 5 athletes were at risk of malnutrition, and 61 athletes were classified as being overweight and obese.

Figure $1 \mathrm{~A}$ shows that the diets $\mathrm{F}$ and $\mathrm{F}+\mathrm{S}$ did not present any statistical differences regarding the inadequacies due to insufficient energy and macronutrient intake, and the prevalence of similar inadequacies was similar between the two diets (energy $\mathrm{F}$ and $\mathrm{F}+\mathrm{S} p=0.172$, Carbohydrates ( $\mathrm{CHO}$ ) F and FS $p=0.681$; Protein (PTN) $F$ and $F+S p=0.109$ ). In Figure $1 B$, there was no difference in the prevalence of inadequacy related to excessive intake of lipids and energy (energy $F$ and $F+S p=1.0$, LIP $F$ and $F S p=0.600$ ), but for protein intake, inadequacies increased in the $\mathrm{F}+\mathrm{S}$ diet $(p=0.026)$, with a $10.4 \%$ increase in the prevalence of inadequacy due to excessive intake of proteins in the $\mathrm{F}+\mathrm{S}$ diet compared to diet F. No athlete presented carbohydrate intake higher than the recommended doses.

Considering the difference between estimated and real energy expenditure between 
A

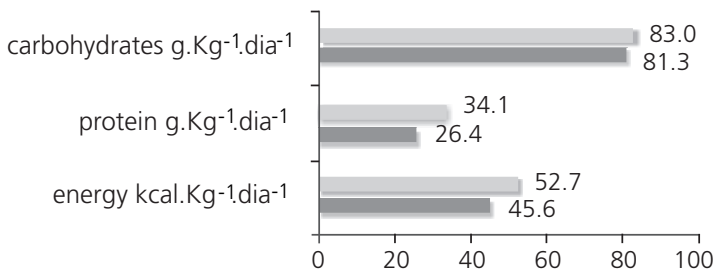

Estimated intake prevalence below recommendation (\%)

$$
F=F+S
$$

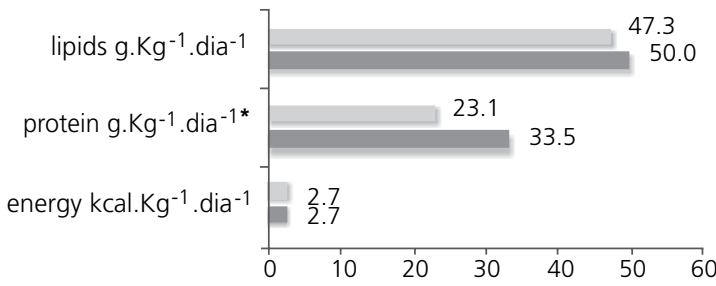

Estimated intake prevalence above recommendation (\%)

$$
\mathrm{F}=\mathrm{F}+\mathrm{S}
$$

Figure 1. Prevalence of calorie and macronutrient intake below (a) and above (b) recommendation for athletes between the Food (F) and Food+Supplementation diets (F+S). Cuiabá (MT), Brazil (2014).

Note: * Statistical difference in protein intake between $\mathrm{F}$ and $\mathrm{F}+\mathrm{S}$ diets.

Table 4. Mean and standard deviation of energy and macronutrient intake for Food (F) and Food and Supplementation $(F+S)$ diet by

\begin{tabular}{|c|c|c|c|c|c|c|c|c|c|}
\hline \multirow[t]{2}{*}{ Macronutrients } & \multirow{2}{*}{$\begin{array}{l}\mathrm{F} \text { or } \\
\mathrm{F}+\mathrm{S}\end{array}$} & \multicolumn{2}{|c|}{$\begin{array}{l}\text { Strenght/speed } \\
\qquad(n=35)\end{array}$} & \multicolumn{2}{|c|}{$\begin{array}{l}\text { Intermittent } \\
\quad(\mathrm{n}=77)\end{array}$} & \multicolumn{2}{|c|}{$\begin{array}{l}\text { Fighting/shooting } \\
\qquad(n=56)\end{array}$} & \multicolumn{2}{|c|}{$\begin{array}{l}\text { Endurance } \\
\qquad(n=14)\end{array}$} \\
\hline & & M & SD & M & SD & M & SD & & \\
\hline \multirow[t]{2}{*}{ kcal.day $^{-1}$} & $\mathrm{~F}$ & 2349.0 & 743.0 & 2110.0 & 536.0 & 2249.0 & $491.0^{\mathrm{ab}}$ & 1979.0 & 559.0 \\
\hline & $\mathrm{F}+\mathrm{S}$ & 2762.0 & $888.0^{\text {bcd }}$ & 2145.0 & 536.0 & 2280.0 & 480.0 & 2081.0 & 583.0 \\
\hline \multirow[t]{2}{*}{ kcal.kg ${ }^{-1} \cdot$ day $^{-1}$} & $\mathrm{~F}$ & 33.0 & 11.0 & 27 & 9.0 & 33.0 & 8.0 & 31.0 & 9.0 \\
\hline & $\mathrm{F}+\mathrm{S}$ & 39.0 & 11.0 & 28 & 9.0 & 34.0 & $8.0^{\mathrm{ab}}$ & 33.0 & 10.0 \\
\hline \multirow[t]{2}{*}{$\mathrm{CHO}\left(\mathrm{g} \cdot \mathrm{kg}^{-1} \cdot\right.$ day $\left.^{-1}\right)$} & $A$ & 4.1 & 1.9 & 3.3 & 1.2 & 4.1 & $1.2^{\mathbf{b}}$ & 4.0 & 1.5 \\
\hline & $\mathrm{F}+\mathrm{S}$ & 4.4 & 1.9 & 3.4 & 1.2 & 4.2 & $1.2^{\mathrm{ab}}$ & 4.0 & 1.5 \\
\hline \multirow[t]{2}{*}{ CHO (g.day $\left.{ }^{-1}\right)$} & $\mathrm{F}$ & 286.7 & 122.0 & 257.7 & 71.1 & 279.6 & 72.7 & 252.4 & 93.7 \\
\hline & $\mathrm{F}+\mathrm{S}$ & 307.0 & 118.0 & 260.2 & 71.2 & 283.8 & 72.8 & 253.9 & 93.7 \\
\hline \multirow[t]{2}{*}{$\mathrm{CHO}(\%)$} & $\mathrm{F}$ & 48.7 & 11.5 & 49.1 & 7.2 & 49.9 & 8.0 & 50.3 & 6.4 \\
\hline & $\mathrm{F}+\mathrm{S}$ & 45.1 & 11.1 & 48.7 & $6.8^{a}$ & 49.9 & 8.0 & 48.3 & 7.2 \\
\hline \multirow[t]{2}{*}{ Protein $\left(\mathrm{g} \cdot \mathrm{kg}^{-1} \cdot\right.$ day $\left.^{-1}\right)$} & $\mathrm{F}$ & 1.9 & $0.7^{\mathrm{cd}}$ & 1.2 & 0.6 & 1.5 & $0.7^{\mathbf{b}}$ & 1.3 & 0.4 \\
\hline & $\mathrm{F}+\mathrm{S}$ & 2.6 & $1.0^{\mathrm{bcd}}$ & 1.3 & 0.6 & 1.6 & $0.7^{b}$ & 1.6 & 0.6 \\
\hline \multirow[t]{2}{*}{ Protein (g.day-1) } & $\mathrm{F}$ & 136.1 & $66.7^{\text {bcd }}$ & 96.3 & 36.8 & 102.0 & 35.4 & 82.7 & 19.9 \\
\hline & $\mathrm{F}+\mathrm{S}$ & 191.7 & $90.1^{\text {bcd }}$ & 101.5 & 38.4 & 105.0 & 34.8 & 103.0 & 40.7 \\
\hline \multirow[t]{2}{*}{ Protein (\%) } & $\mathrm{F}$ & 23.1 & $8.1^{b c}$ & 18.1 & 4.7 & 18.2 & 5.2 & 17.2 & 3.7 \\
\hline & $\mathrm{F}+\mathrm{S}$ & 27.2 & $8.8^{\mathrm{bcd}}$ & 18.8 & 4.4 & 18.5 & 5.1 & 20.0 & 5.8 \\
\hline \multirow[t]{2}{*}{ Lipids $\left(\mathrm{g} \cdot \mathrm{kg}^{-1} \cdot\right.$ day $\left.^{-1}\right)$} & $\mathrm{F}$ & 1.1 & 0.5 & 1.0 & 0.4 & 1.1 & 0.3 & 1.1 & 0.3 \\
\hline & $\mathrm{F}+\mathrm{S}$ & 1.1 & 0.4 & 1.0 & 0.4 & 1.1 & $0.3^{\mathbf{b}}$ & 1.1 & 0.3 \\
\hline \multirow[t]{2}{*}{ Lipids (g.day ${ }^{-1}$ ) } & $\mathrm{F}$ & 72.5 & 27.0 & 75.2 & 25.4 & 76.3 & 19.2 & 71.0 & 21.1 \\
\hline & $\mathrm{F}+\mathrm{S}$ & 76.8 & 27.1 & 75.6 & 25.4 & 76.4 & 19.1 & 72.3 & 21.1 \\
\hline \multirow[t]{2}{*}{ Lipids (\%) } & $\mathrm{F}$ & 28.1 & $7.0^{\mathbf{b}}$ & 31.8 & 5.2 & 30.6 & 4.4 & 32.3 & 4.4 \\
\hline & $\mathrm{F}+\mathrm{S}$ & 25.8 & $7.1^{\mathrm{bcd}}$ & 31.4 & 5.7 & 30.3 & 4.6 & 31.4 & 4.4 \\
\hline $\begin{array}{l}\text { Energy expenditure } \mathrm{kcal}^{-1} \text {. } \\
\text { day-1 }\end{array}$ & & 2413.0 & 544.0 & 4063.0 & 1304.0 & 2855.0 & $859.0^{\text {ab }}$ & 2932.0 & 862.0 \\
\hline
\end{tabular}
sports modality group. Cuiabá (MT), Brazil (2014).

Note: Values reported as means (standard deviation). Different letters indicate statistical difference between groups, where ${ }^{a}$ power/speed;

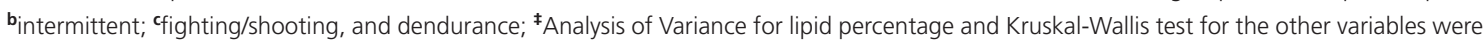
used to compare modalities.

M: Mean; SD: Standard Deviation. 
men and women, both presented an energy deficit, which was higher among men $\left(-1163.3 \mathrm{kcal}\right.$ day $\left.^{-1}\right)$ than among females

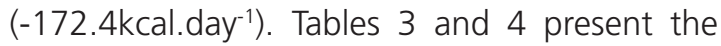
mean values of energy and nutrient intake for the total sample, according to gender and groups of sports modalities, respectively.

As expected, the absolute energy intake of men was significantly higher than of women in $\mathrm{F}$ and $\mathrm{F}+\mathrm{S}$ diets. However, the opposite occurred with energy related to weight, indicating higher intake among women in both $\mathrm{F}$ and $\mathrm{F}+\mathrm{S}$ diets. The power/speed group presented higher total and relative energy intake when compared with the other diet and supplementation groups. The only group that did not reach the minimum energy intake related to body weight was the intermittent group, even when considering energy values from supplements (Table 4).

As for the carbohydrate intake, neither both genders nor sports modalities reached the recommended values (5.0-10.0 g. $\mathrm{kg}^{-1}$. day ${ }^{-1}$ ), even with dietary supplementation (Table 3 and 4 ).

The data of protein intake with and without supplementation showed a statistical difference for all the measurement units of intake per gender and sports modality, as shown in Tables 4 and 5. Regarding the intake related to body weight, women presented a higher value in both $\mathrm{F}$ and $\mathrm{F}+\mathrm{S}$ dietary groups. The athletes in the power/speed group presented higher protein intakes in both diets $(\mathrm{F}$ and $\mathrm{F}+\mathrm{S}$ ) in comparison with all measurement units of intake in the other groups (g.day ${ }^{-1}, \mathrm{~g} \mathrm{~kg}^{-1}$.day ${ }^{-1}$, and percentage).

As for the lipids, intake related to body mass was higher among women than men. Among the sports modalities, the power/speed group presented a lower proportion of energy from lipids in the $\mathrm{F}+\mathrm{S}$ diet than the other groups.

\section{DISCUSSION}

In general, our results indicate that the prevalence of energy and macronutrient inadequacy was high among athletes of both genders and sports modalities, especially concerning calories, carbohydrates and lipids, characterizing a hypocaloric, hypoglycemic and hyperlipidemic diet in diets with or without supplementation. The use of dietary supplements did not significantly alter the energy, glucose and lipid intake, but it significantly increased the daily protein intake, also increasing the inadequacy values due to excessive protein intake. Chronic or periodic energy restriction is commonly observed in athletes and it may be influenced, among other factors, by the pressure and strict weight and/or body fat limits imposed on some sports modalities (artistic gymnastics, fighting, among others) $[23,24]$.

Other studies corroborate these results with regard to low glycemic intake $[23,25]$. In a literature review conducted by Burke et al. [26], the authors pointed out an apparent increase in carbohydrate intake over the decades, although values below the specific recommendations for athletes can be observed in the data itself. Some of the possible reasons for inadequate carbohydrate intake discussed by those authors are the lack of more specific recommendations tailored to the actual needs of athletes, taking into account the preparation phase, lack of knowledge about the benefits of carbohydrates in the diet, difficult recommendations to achieve, and the purposeful restriction of total energy intake, which requires further research to confirm this information.

Contrary to other studies available in the literature $[4,27]$, our findings show that the relative intake of all macronutrients $\left(\mathrm{g} \cdot \mathrm{kg}^{-1}\right.$. day $^{-1}$ ) and, consequently, energy was higher among women. These results, however, are in agreement with those found by Hinton et al. [23] with female athletes of various modalities (volleyball, soccer, football, swimming/diving, tennis, among others). The differences between genders are attributed to the lower caloric density and nutrients in the diet of male athletes. 
Regarding proteins, bodybuilding was the predominant sports modality in the power/ speed group in the present study and therefore, athletes were expected to ingest more protein supplements, consequently increasing the protein and calorie intake in comparison with the others groups, reaching energy balance as this sports modality seeks muscle hypertrophy to increase strength, power and esthetics [28].

However, in all the categories analyzed, mean protein intake met the minimum value recommended $\left(1.2 \mathrm{~g} \mathrm{~kg}^{-1}\right.$. day $\left.{ }^{-1}\right)$, even without supplementation. In fact, the use of dietary supplements increased the number of athletes with hyperproteic diets $(>1.7 \mathrm{~g})$. On the other hand, the prevalence of inadequacy due to protein intake below the recommended dose was low (22.0\% of the athletes) in the present study, but surprisingly higher among men $(31.3 \%)$ when compared to women (9.4\%).

Based on the results of the present study, we can raise important practical considerations. Firstly, it would be more plausible for athletes to increase their intake of glycemic foods or to opt for supplements with more carbohydrates than protein content, as protein intake is already adequate. Secondly, it is quite reasonable to consider, through comparison with nutritional recommendations, that the calorie intake of athletes in this study should be higher. However, professionals should be aware that the athlete's nutritional status is the result not only of food consumption, but also of anthropometric and biochemical indicators.

Although almost all categories show an energy deficit, the BMI was within normality for most of them, indicating good nutritional status. Thus, the combination of these indicators is fundamental for dietary prescription. Therefore, athletes need to be regularly evaluated and monitored throughout the different training phases, considering the specific factors of the individuals and the sports modalities practiced (types of exercises, intensity, duration and time, among others).
It is noteworthy that, to date, no studies reporting the reduction or increase of inadequacies from dietary supplement intake have been found. Few studies that have researched these substances only focused on the contribution of dietary supplements to energy and macronutrient intake of athletes [4,29].

However, the limitations of this article must be highlighted. Although the 24-HDR is a widely accepted method, considered as the gold standard for the validation of other instruments for food intake assessment [30], it may be applied on an atypical day of the individual tending to underestimate or even overestimate intake, as this method depends on the total collaboration, honesty, memory and previous knowledge of the interviewee about food [30].

In this study, the 24-HDR was applied in a short time interval (two nonconsecutive days) and may not have reflected the seasonal changes in the athletes' diet, especially related to the different training and competition phases. However, statistical methods were used to estimate the habitual intake of the individuals studied to minimize the limitations of the nonreapplication of the $24-H D R$, in addition to the usual measurements of the dietary supplements (scoop, capsules, bars, among others), which may have increased the accuracy of the measurements.

\section{CONCLUSION}

The intake of supplements did not significantly decrease the values of inadequacy. However, it significantly increased protein intake, also increasing the inadequacy of excessive protein intake. Supplement intake may be a good alternative to meet the nutritional needs established by dietary guides; however, supplemental choices among athletes need to be better targeted.

Thus, it is worth mentioning the important role of the nutritionist for adequate 
food consumption, who shall indicate the use of supplements according to the actual needs of the athletes, considering the sports modality and the individual objectives, as this may influence performance.

\section{ACKNOWLEGMENTS}

The development and data collection of the present study would have not been possible without the research grants from the Coordenação de Aperfeiçoamento de Nivel Superior and Conselho Nacional de Desenvolvimento Científico e Tecnológico.

\section{CONTRIBUTORS}

All authors participated in all phases of the research

\section{REFERENCES}

1. American College of Sports Medicine, American Dietetic Association, Dietitians of Canada. Nutrition and athletic performance. Med Sci Sports Exerc. 2009;41(3):709-31. https://doi. org/10.1249/MSS.0b013e318190eb86

2. Sociedade Brasileira de Medicina do Esporte. Modificações dietéticas, reposição hídrica, suplementos alimentares e drogas: comprovação de ação ergogênica potenciais riscos para a saúde. Rev Bras Med Esporte. 2009;15(3):3-12. https:// doi.org/10.1590/S1517-86922009000400001

3. Panza VP, Coelho MSPH, Pietro PF, Assis MAA, Vasconcelos FAG. Consumo alimentar de atletas: reflexões sobre recomendações nutricionais, hábitos alimentares e métodos para avaliação do gasto e consumo energéticos. Rev Nutr. 2007;20(6):681-92. https://doi.org/10.1590/S1415-5 2732007000600010

4. Lun V, Erdman KA, Reimer RA. Evaluation of nutritional intake in Canadian high-performance athletes. Clin J Sport Med. 2010;19(5):405-11. https://doi.org/10.1097/JSM.0b013e3181b5413b

5. Valliant MW, Emplaincourt HP, Wenzel RK, Garner $\mathrm{BH}$. Nutrition education by a registered dietitian improves dietary intake and nutrition knowledge of a NCAA female volleyball team. Nutrients. 2012;4(6):506-16. https://doi.org/10.3390/nu4060 506
6. Molina-López J, Molina JM, Chirosa LJ, Florea D, Sáez $L$, Jiménez J, et al. Implementation of a nutrition education program in a handball team; consequences on nutritional status. Nutr Hosp. 2013;28(3):1065-76. https://doi.org/10.3305/ nh.2013.28.4.6600

7. Huang SSH, Johnson K, Pipe AL. The use of dietary supplements and medications by Canadian athletes at the Atlanta and Sydney Olympic Games. Clin J Sport Med. 2006 [cited 2015 May 27];16(1):27-33. http://insights.ovid.com/ pubmed?pmid $=16377972$

8. Lane J. The next Chapter in sports nutrition: The category continues to wield enormous power in the dietary supplement market, so where will it go from here? The sky's the limit. Nutraceuticals World Mag. 2012 [cited 2015 Jan 12];(5). Available from: http://www. nutraceuticalsworld. com/issues/2012-05/view_features/the-nextchapter-in-sports-nutrition/\#sthash.kQpvKCms. dpuf

9. Molinero O, Márquez S. Use of nutritional supplements in sports: Risks, knowledge, and behavioural-related factors. Nutr Hosp. 2009 [cited 2015 May 15];24(2):128-34. Available from: http://www.aulamedica.es/gdcr/index.php/ nh/article/view/4300

10. Zabotto CB, Vianna RPT, Gil M. Registro fotográfico para inquéritos dietéticos: utensílios e porções. Campinas: Unicamp; 1996.

11. Food and Drug Administration. Dietary supplement health and education act of 1994. Bethesda (MD): National Institutes of Health; 1994 [cited 2015 Oct 10]. Available from: https://ods.od.nih.gov/ About/DSHEA_Wording.aspx. 1994

12. Universidade Estadual de Campinas. Tabela brasileira de composição de alimentos. $4^{a}$ ed. rev. ampl. Campinas: Unicamp; 2011 [acesso 2015 maio 12]. Disponível em: http://www.unicamp.br/ nepa/taco/tabela. php?ativo=tabela

13. Pinheiro ABV, Lacerda EMA, Benzecry EH, Gomes MCV. Tabela para avaliação de consumo alimentar em medidas caseiras. $5^{\text {a }}$ ed. São Paulo: Atheneu; 2004.

14. Instituto Brasileiro de Geografia e Estatística. Tabela de composição de alimentos. $5^{a}$ ed. Rio de Janeiro: IBGE; 1999 [acesso 2015 maio 12]. Disponível em: biblioteca.ibge.gov.br/visualizacao/ livros/liv50002.pdf

15. Nabuco HCG, Rodrigues VB, Barros WM, Ravagnani FCP, Espinosa MM, Ravagnani CFC. Uso de suplementos alimentares entre atletas brasileiros. Rev Nutr. 2017;30(2):163-73. https:// doi.org/10.1590/1678-98652017000200002 
16. Haubrock J, Nöthlings U, Volatier JL, Dekkers A, Ocké $M$, Hartting $U$, et al. Estimating usual food intake distributions by using the multiple source method in the EPIC-potsdam calibration study. J Nutr. 2011;141(5):914-20. https://doi.org/10. 3945/jn. 109.120394

17. Wiens J, Erdman KE, Standnyk M, Parnell JA. Dietary supplement usage, motivation, and education in young, Canadian athletes. Int J Sport Nutr Exerc Metab. 2014 [cited 2015 Mar 27];24(06):613-22. https://doi.org/10.1123/ijsnem. 2013-0087

18. World Health Organization. Obesity: Preventing and managing the global epidemic. Technical Report Series, n 894. Geneva: WHO; 2000 [cited 2015 Apr 9]. Available from: http://www.who.int/ nutrition/publications/obesity/WHO_TRS_894/en/

19. Onis M, Onyango AW, Borghi E, Siyam A, Nishida C, Siekmann J. Development of a WHO growth reference for school-aged children and adolescents. Bull World Health Organ. 2007;85(9):660-7. https://doi.org/10.2471/BLT.07. 043497

20. World Health Organization, Food and Agriculture Organization of the United Nations, United Nations University. Human energy requirements. Geneva: WHO; 2001 [cited 2015 Aug 28]. Available from: http://www.who.int/nutrition/ publications/nutrientrequirements/9251052123/ en/

21. Ainsworth BE, Haskell WL, Whitt $M C$, Irwin $M L$, Swartz AM, Strath SJ, et al. Compendium of physical activities: An update of activity codes and MET intensities. Med Sci Sports Exerc. 2000 [cited 2015 May 28];32(9Suppl.):498-504. Available from: http://journals.lww.com/acsm-msse/ Fulltext/2000/09001/Compendium_of_Physical_ Activities_an_update_of.9.aspx

22. Tarso P, Farinatti V. Apresentação de uma versão em Português do compêndio de atividades físicas: uma contribuição aos pesquisadores e profissionais em fisiologia do exercício. Rev Bras Fisio Exer. 2003;2:177-208.
23. Hinton PS, Sanford TC, Davidson MM, Yakushko OF, Beck NC. Nutrient intakes and dietary behaviors of male and female collegiate athletes. Int J Sport Nutr Exerc Metab. 2004;14(4):389-405.

24. Farajian P, Kavouras SA, Yannakoulia M, Sidossis LS. Dietary intake and nutritional practices of elite Greek aquatic athletes. Int J Sport Nutr Exerc Metab. 2004 [cited 2015 Apr 30];14(5):574-85. https://doi.org/10.1123/ijsnem.14.5.574

25. Pettersson S, Berg CM. Dietary intake at competition in elite olympic combat sports. Int J Sport Nutr Exerc Metab. 2014 [cited 2014 Jul 24];24(1):98-109. https://doi.org/10.1123/ijsnem. 2013-0041

26. Burke LM, Cox GR, Cummings NK, Desbrow B. Guidelinesfordailycarbohydrateintake:Doathletes achieve them? Sports Med. 2001;31(4):267-99. https://doi.org/10.2165/00007256-20013104000003

27. Tarnopolsky MA. Females and males: Should nutritional recommendations be gender specific? Schweiz Z Med Traumatol. 2003 [cited 2015 Jun 3];51(1):39-46. Available from: http://www.sgsm.ch/fileadmin/user_upload/ Zeitschrift/51-2003-1/08-2003-1.pdf

28. Slater G, Phillips SM. Nutrition guidelines for strength sports: Sprinting, weightlifting, throwing events, and bodybuilding. J Sports Sci. 2011;29(S1):S67-77. https://doi.org/10.1080/026 40414.2011.574722

29. Nogueira JAD, da Costa T. Nutrient intake and eating habits of triathletes. Int J Sport Nutr Exerc Metab. 2004;14(6):684-97. https://doi.org/10.1123/ ijsnem. 14.6.684

30. Buzzard M. 24-hour dietary recall and foodrecord methods. In: Willet W. Nutritional epidemiology. 2nd ed. New York: Oxford University Press; 1998. https://doi.org/10.1093/ acprof:oso/9780195122978.003.04

Received: April 19, 2016

Final version: December 6, 2016 Approved: January 4, 2017 
